\title{
Analisis Peran Orang Tua dalam Mendampingi Anak di Masa Pandemi Covid-19
}

\author{
Euis Kurniati ${ }^{{ }_{1}}$, Dina Kusumanita Nur Alfaeni2 ${ }^{2}$, Fitri Andriani ${ }^{3}$ \\ Pendidikan Guru Pendidikan Amak Usia Dini, Universitas Pendidikan Indonesia \\ DOI: $10.31004 /$ obsesi.v5i1.541
}

\begin{abstract}
Abstrak
Artikel ini bertujuan untuk mengetahui peran apa saja yang dirasakan orang tua selama mendampingi anak di masa pandemi Covid-19. Metode yang digunakan studi kasus melalui wawancara dengan analisis tematik pada 3 Ayah dan 6 Ibu. Hasil menunjukkan bahwa secara umum peran yang muncul adalah sebagai pembimbing, pendidik, penjaga, pengembang dan pengawas. Secara khusus peran yang muncul yaitu: menjaga dan memastikan anak untuk menerapkan hidup bersih dan sehat, mendampingi anak dalam mengerjakan tugas sekolah, melakukan kegiatan bersama selama di rumah, menciptakan lingkungan yang nyaman untuk anak, menjalin komunikasi yang intens dengan anak, bermain bersama anak, menjadi role model bagi anak, memberikan pengawasan pada anggota keluarga, menafkahi dan memenuhi kebutuhan keluarga, dan membimbing dan memotivasi anak, memberikan edukasi, memelihara nilai keagamaan, melakukan variasi dan inovasi kegiatan di rumah. Diperlukan panduan bagi orang tua dalam membantu mendampingi kegiatan anak yang berbasis pada kebutuhan anak selama pandemi dan BDR.
\end{abstract}

Kata Kunci: peran orang tua; anak; bdr; masa pandemi.

\begin{abstract}
The aims of this article are to find out what parent roles when accompanying child in Covid19 era. The method used was a case study through interviews with thematic analysis of 3 fathers and 6 mothers. The study indicate that in general the roles of parent as a guidance, educator, guardian, developer, and supervisor, and speciffically the roles that appear namely: maintaining and ensuring children to implement clean and healthy living, assisting children in doing school work, doing joint activities while at home, creating a comfortable environment for children, establish intense communication with children, play with children, becoming a role model for children, provide supervision to family members, provide for and meet family needs, and guide and motivate children, provide education, maintain religious values, conduct variation and innovation of activities at home. Guidelines needed for parents based on children need during the pandemi and school from home.
\end{abstract}

Keywords: parent roles; child; sfh; pandemic era

Copyright (c) 2020 Euis Kurniati, Dina Kusumanita Nur Alfaeni, Fitri Andriani

$\triangle$ Corresponding author:

Email Address : euiskurniati@upi.edu (Bandung Jawabarat, Indonesia)

Received 19 May 2020, Accepted 30 May 2020, Published 31 May 2020 


\section{PENDAHULUAN}

Dunia saat ini disibukkan dengan munculnya virus corona (Covid-19). Terhitung tanggal 26 Mei 2020 virus ini telah menginfeksi 5,623,503 orang, dengan jumlah kematian 348,760 jiwa dan jumlah pasien yang sembuh 2,393,551 serta menginfeksi 213 negara (worldometers.info, 2020). Di Indonesia sendiri, penyebaran virus ini ditemukan pertama kali pada tanggal 2 maret 2020, dan hal ini disampaikan langsung oleh Presiden Joko Widodo (Nuraini, 2020), dan saat ini telah menginfeksi 23,165 orang dengan jumlah kematian 1,418 jiwa, dan jumlah pasien yang sembuh 5,877 orang (covid19.go.id, 2020).

Berbagai upaya dilakukan pemerintah untuk memutus mata rantai penyebaran virus ini, di antaranya adalah dengan mengeluarkan PP Nomor 21 tahun 2020 tentang Pembatasan Sosial Berskala Besar Dalam Rangka Percepatan Penanganan Covid-19 yang berakibat pada pembatasan berbagai aktivitas termasuk di antaranya sekolah. Sementara itu aktivitas Belajar Dari Rumah (BDR) secara resmi di keluarkan melalui Surat Edaran Mendikbud Nomor 36962/MPK.A/HK/2020 tentang pembelajaran secara daring dan bekerja dari rumah dalam rangka pencegahan penyebaran Corona Virus Disease (COVID- 19). Kebijakan ini memaksa guru dan murid untuk tetap bekerja dan belajar dari rumah dari jenjang PAUD sampai Perguruan Tinggi (kemdikbud.go.id, 2020). Kebijakan ini tentunya tidak hanya berdampak pada relasi guru dan murid selama BDR, namun juga pentingnya optimalisasi peran orang tua dalam pelaksanaan BDR.

Peran orang tua dalam mendampingi kesuksesan anak selama belajar di rumah menjadi sangat sentral, sekaitan dengan hal tersebut WHO, (2020) merilis berbagai panduan bagi orang tua dalam mendampingi putra-putri selama pandemi ini berlangsung yang meliputi tips pengasuhan agar lebih positif dan konstuktif dalam mendampingi anak selama beraktivitas di rumah. Orang tua pada awalnya berperan dalam membimbing sikap serta keterampilan yang mendasar, seperti pendidikan agama untuk patuh terhadap aturan, dan untuk pembiasaan yang baik (Nurlaeni \& Juniarti, 2017), namun perannya menjadi meluas yaitu sebagai pendamping pendidikan akademik. Prabhawani (2016) menyatakan bahwa pelaksanaan pendidikan merupakan tanggung jawab orang tua dan masyarakat sekitar, tidak hanya tanggung jawab lembaga pendidikan saja.

Berbicara tentang peran orang tua, tidak terlepas dari keluarga. Lestari, (2012) menyatakan bahwa keluarga dilihat dari fungsinya yakni memiliki tugas dan fungsi perawatan, dukungan emosi dan materi, serta pemenuhan peranan tertentu. Sejalan dengan hal tersebut, Muchtar (dalam Lutfatutatifah et al., 2015) mengugkapkan bahwa keluarga merupakan bagian penting dari unit masyarakat. Keluarga memiliki peran penting dalam merawat, mendidik, melindungi dan mengasuh anak. Menurut Candra et al. (2013) menyatakan bahwa pengasuhan orang tua terhadap anaknya dapat berpengaruh terhadap pembentukan karakter dan perilaku anak itu sendiri. Apabila terdapat kesalahan pengasuhan maka akan berdampak pada anak saat sudah dewasa. Sejalan dengan hal tersebut Rakhmawati, (2015) menyatakan bahwa pengasuhan anak merupakan suatu kegiatan berkelanjutan melalui proses interaksi orang tua dan anak untuk mendorong pertumbuhan serta perkembangan anak yang optimal. Paparan di atas menunjukkan bahwa selama ini, peran orang tua dalam pengasuhan dan perawatan lebih menonjol, sementara pendidikan akademik seringkali dialih tugaskan kepada pihak kedua yaitu sekolah sebagaimana yang dipaparkan Rosdiana, (2006) bahwa faktanya kebanyakan orang tua masih merasa bahwa kewajibannya dalam mendidik anak telah usai setelah memasukannya ke suatu lembaga persekolahan.

Paparan peran orang tua di atas, lebih banyak dianalisis saat sebelum terjadi pandemi yang mana lebih menekankan pada pengasuhan dan perawatan, sementara pendidikan akademik lebih banyak diserahkan pada pihak sekolah. Sementara itu penelitian yang terkait dengan peran orang tua saat terjadi pandemi belum banyak dilakukan. 
Berdasarkan hal tersebut di atas, kajian dalam penelitian ini menjadi sangat penting dilakukan untuk memahami bagaimana sebenarnya peran orang tua dalam mendampingi putra-putrinya saat terjadi pandemi Covid-19 termasuk di antaranya saat mendampingi anak belajar dari rumah.

\section{METODOLOGI}

Metode yang digunakan dalam penelitian ini adalah studi kasus, yaitu desain penelitian yang digunakan untuk mengungkap secara lebih rinci dan komprehensif mengenai situasi dari objek yang dianalisis (Alwasilah, 2002). Yin, (2003) menyatakan bahwa studi kasus sangat sesuai untuk menjawab pertanyaan "bagaimana" karena jenis pertanyaan seperti ini akan mengekplorasi data lebih dalam. Dalam hal ini penelitian menganalisis peran orang tua mengenai peran mereka dalam mendampingi anak selama pandemi Covid19 terjadi. Subjek dalam penelitian ini adalah orang tua yang memiliki anak usia dini dan usia sekolah dasar dengan jumlah 9 orang (3 Ayah, $6 \mathrm{Ibu}$ ). Teknik pengumpulan data yang digunakan adalah wawancara dan data dianalisis dengan menggunakan tematik, yaitu teknik analisis yang menekankan pada penyusunan koding dengan mengacu pada pertanyaan penelitian yang telah ditetapkan, sehingga tema-tema yang tersusun sesuai dengan pertanyaan penelitian tersebut dan menjadi acuan dalam memaparkan fenomena yang terjadi (Heriyanto, 2018). Secara lebih rinci paparan alur penelitian dapat dilihat pada gambar 1 di bawah ini.

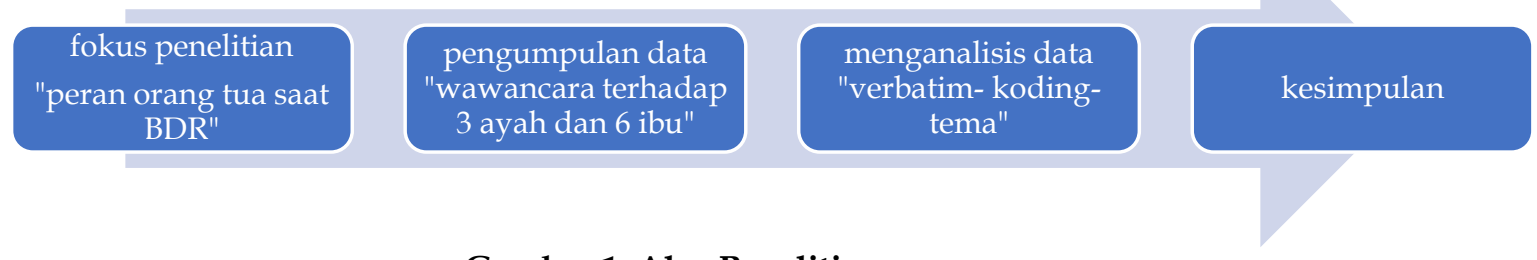

\section{Gambar 1. Alur Penelitian}

\section{HASIL DAN PEMBAHASAN}

Peristiwa pandemi Covid-19 yang terjadi dihampir seluruh dunia ini, menunjukkan semakin pentingnya peran keluarga dalam mengasuh, merawat dan juga mendidik anak. Peristiwa ini mengembalikan fungsi awal keluarga sebagai pusat segala kegiatan, tempat terjadinya pendidikan yang utama untuk anak. Sebagaimana dipaparkan oleh salah satu orang tua di bawah ini.

...ya mengembalikan fungsi awal keluarga sebagai tempat pusat segala kegiatan...ya...mengembalikan kebersamaan .. keakraban... (kutipan wawancara SP)

Keluarga tidak dapat dipisahkan dari kehidupan anak, yang merupakan tempat utama dan pertama dalam memulai kehidupannya. Di dalam keluarga nilai, agama, moral, serta sosial dapat dilakukan lebih efektif ketimbang dilakukan di institusi lainnya. Seperti yang diungkapkan oleh Zahrok \& Suarmini, (2018) bahwa keluarga berperan penting dalam menanamkan kebiasaan dan pola tingkah laku, serta menanamkan nilai, agama, dan moral sesuai dengan usia dan kultur di keluarganya. Dalam Peraturan Pemerintah Republik Indonesia Nomor 21 Tahun 1994 Tentang Penyelenggaraan Pembangunan Keluarga Sejahtera, 1994 dinyatakan bahwa keluarga memiliki fungsi cinta dan kasih sayang, perlindungan, pendidikan, nilai, agama, moral, serta sosial. Alfiana, (2013) menyatakan bahwa keluarga merupakan tempat utama atau tempat awal dan tempat terdekat anak, karena dalam keluarga tersedia banyak waktu luang untuk dihabiskan bersama dengan anak. Zahrok \& Suarmini, (2018) juga menyatakan bahwa keluarga menjadi satu bagian yang paling penting dalam menjadikan anak lebih baik salah satunya adalah dengan pendidikan, 
keluarga menjadi salah satu pusat pendidikan untuk anak (Alfiana, 2013; Zahrok \& Suarmini, 2018). Secara lebih spesifik, peran orang tua yang tercermin selama terjadinya masa pandemi Covid-19 akan di paparkan dibawah ini.

\section{Menjaga dan Memastikan Anak untuk Menerapkan Hidup Bersih dan Sehat.}

Setiap orang tua pasti menginginkan anaknya selalu dalam keadaan sehat, apalagi dengan kondisi saat ini yaitu pada masa pandemi COVID-19 tentu saja orang tua menjadi semakin khawatir akan hal itu. Salah satu yang dapat di lakukan orang tua adalah mengingatkan anak nya untuk selalu menerapkan pola hidup sehat dan bersih agar terhindar dari berbagai penyakit dan dengan mengajarkan anak untuk mengikuti protokol kesehatan. Sejalan dengan yang diungkapkan oleh Rompas et al., (2018) yang menyatakan bahwa orang tua memiliki peran yang sangat penting dalam hal mendidik anak, salah satunya adalah menjadi dan memberikan contoh yang baik untuk anak, selain itu memberikan peringatan dan nasihat pada anak juga merupakan hal penting yang harus dilakukan orang tua agar selalu hidup bersih kepada anak.

... menjaga kesehatan anak, memastikan anak selalu sehat dan tetap menjaga pola hidup sehat, lalu memastikan agar anak selalu mengikuti anjuran pemerintah tentang bagaimana menjalankan SOP pencegahan virus... (kutipan wawancara MN)

... keluar harus pake masker, berjemur di pagi hari sambil di ajak main... (kutipan wawancara EI)

Menurut Graha (2007) perlakuan orang tua yang selalu memberikan pengertian dan latihan kepada anak tentang kebersihan dan kerapihan, akan dapat menjadikan anak selalu menjaga kebersihan diri. Tidak hanya mengingatkan untuk menjaga pola hidup sehat, peran orang tua juga adalah untuk menjaga dan memastikan agar anak tetap sehat, serta memastikan bahwa anak menerapkan pola hidup sehat dengan benar. Oktaviani et al. (2017) menyatakan bahwa orang tua memberikan kasih sayang kepada anak nya tidak hanya dalam bentuk pendidikan dan kepercayaan, tetapi juga penting untuk selalu mengontrol perkembangan anaknya. Seperti yang kita tahu anak bisa lebih cepat belajar dengan meniru, sehingga penting keteladanan dan pembiasaan yang di berikan oleh pengajarnya, khususnya orang tua. Hal tersebut juga sejalan dengan pendapat Ihsani \& Santoso (2020) bahwa peran orang tua di rumah sangatlah penting dalam memberikan edukasi kepada anak untuk selalu menjaga kebersihan lingkungan, edukasi tersebut dapat di sampaikan pada anak dengan memberikan contoh untuk selalu mencuci tangan setelah beraktifitas di luar, hal tersebut dinilai penting untuk meningkatkan kesadaran mengenai kebersihan lingkungan. Selain itu peran orang tua untuk memastikan anak mengonsumsi makanan yang bergizi, tidur teratur, rajin mencuci tangan, aktif bermain, dll (Dhiva, 2016).

Melatih anak untuk selalu hidup bersih dan sehat sejalan dengan salah satu kegiatan dalam program pengasuhan positif/positive parenting program (Triple P) yang bertujuan pada pengembangan kapasitas individu untuk pengaturan diri (Sanders, 2008). Pengaturan diri adalah proses dimana individu diajarkan keterampilan untuk mengubah perilaku mereka sendiri dan menjadi solusi dalam masalah di lingkungan sosial yang lebih luas yang berhubungan dengan pengasuhan dan keluarga (Karoly, dalam Sanders, 2008). Positive parenting dapat dijadikan sebagai model pengasuhan keluarga sehingga menjadi solusi dalam menjaga dan memastikan anak menerapkan hidup bersih dan sehat dengan pengaturan diri.

\section{Mendampingi Anak dalam Mengerjakan Tugas Sekolah}

Untuk mencegah mata rantai penularan virus corona di sekolah dikeluarkan kebijakan pelaksanaan pendidikan di masa darurat penyebaran corona virus (COVID-19) oleh Menteri Pendidikan dan Kebudayaan melalui surat edaran pada tanggal 24 Maret 2020, tentang kebijakaan "belajar dari rumah (BDR)". Hal ini mengandung arti bahwa orang tua sementara waktu menggantikan peran guru dalam mendampingi anak belajar di rumah. 
Dari hasil penelaahan data lapangan dapat diketahui bahwa peran orang tua selama masa BDR ini lebih pada membantu mengerjakan tugas yang diberikan oleh guru di sekolah kepada siswa. Kondisi tersebut menunjukkan bahwa kegiatan BDR yang diberikan guru lebih pada pemberian tugas seperti yang diungkapkan oleh Nahdi et al. (2020) bahwa kegiatan yang diberikan oleh lembaga sekolah dalam penerapan pembelajaran di rumah salah satunya adalah pemberian tugas atau penugasan.

... menjadi orang tua sekaligus guru dalam membantu anak mengerjakan tugas-tugas nya dari sekolah (kutipan wawancara UL)

...anak saya kan udah sekolah TK di TK Quran, yang menyelenggarakan belajar online dan banyak tugas-tugas yang memerlukan bimbingan orang tua...(kutipan wawancara SS)

Kondisi tersebut menjadi menarik untuk dikaji, apa sebenarnya makna belajar dari rumah itu? Apakah memiliki makna yang sama dengan mengerjakan tugas atau PR di rumah?. Dengan pemberian tugas seperti itu apakah artinya peran pendampingan belajar anak dapat dikatakan berhasil?. Orientasi pendampingan yang terfokus pada pengerjaan tugas sekolah menunjukkan bahwasannya orientasi pendidikan di Indonesia masih menekankan pada aspek perkembangan kognitif atau pencapaian akademik sehingga perkembangan afeksi dan psikomotor dapat dikatakan tidak menjadi prioritas sehingga kurang terstimulasi. Menurut Mattewakkang, (2020) dalam proses pembelajaran di rumah (BDR) diharapkan guru serta orang tua dapat mewujudkan pendidikan tidak hanya berfokus pada pencapaian akademik atau kognitif nya saja, tetapi dapat mewujudkan pendidikan yang bermakna, dibutuhkan saling pengertian dari pemerintah, sekolah, serta masyarakat dan ketiga elemen tersebut harus saling bersinergi. Demikian pula jika kita tinjau dari tujuan pendidikan nasional yang diatur dalam Undang Undang Republik Indonesia Nomor 20 Tahun 2003 pasal 3, yakni "pendidikan nasional bertujuan untuk berkembangnya potensi peserta didik agar menjadi manusia yang beriman dan bertakwa kepada Tuhan Yang Maha Esa, berakhlak mulia, sehat, berilmu, cakap, kreatif, mandiri, dan menjadi warga negara yang demokratis serta bertanggung jawab".

Melibatkan seluruh komponen pendidikan untuk menjamin pelaksanaan proses pembelajaran dengan suasana yang berbeda yaitu di rumah saja, merancang kurikulum dan pembelajaran yang sesuai dengan kondisi pandemi covid-19, memberikan dorongan motivasi dan apresiasi kepada guru, siswa dan orangtua, melakukan pelatihan daring mengenai pembelajaran jarak jauh (PJJ), mengirimkan laporan tugas harian anak-anak kepada dinas pendidikan melalui daring, melakukan komunikasi tidak hanya satu arah tetapi multi arah untuk mensterilisasi satuan pendidikan adalah hal yang mutlak dilakukan pada kondisi pandemi ini (Ansori, 2020). Posisi orang tua menjadi partner yang sangat penting dalam keberhasilan pendidikan anak-anaknya sehingga perlu dibekali dengan panduan-panduan yang sesuai dengan kebutuhan anak saat ini. Seperti misalnya, panduan mengajarkan perilaku hidup bersih dan sehat, keterampilan menyelesaikan masalah, berfikir kritis, kolaborasi dan komunikasi, literasi informasi media dan teknologi, kreativitas dan inovasi serta ICT yang merupakan keterampilan-keterampilan yang dibutuhkan di abad 21 . Tentu saja proses pendampingan orang tua terhadap anak selama melaksanakan BDR akan membantu pencapaian perkembangan optimal putra putrinya.

... menjadi pendidik bagi anak saat di rumah, seperti mendampingi dalam belajar, membantu ketika ada kesulitan pada anak ...(kutipan wawancara $M N$ )

...sebagai pendidik di rumah kepada anak-anaknya, langsung memberikan bimbingan dan arahan, menggantikan peran guru di sekolah untuk mengadakan pengajaran secara langsung di rumah...(kutipan wawancara SF)

... belajar mandiri dengan orang tua berupa tutorial-tutorial dari sekolah via hp atau online untuk dikerjakan oleh anak kita di rumah, lalu dibimbing dan diarahkan...(kutipan wawancara SF) 
Kutipan wawancara di atas menunjukkan bahwa pada dasarnya upaya pendampingan dapat dilakukan melalui berbagai macam cara seperti di antaranya membantu ketika ada kesulitan, mengadakan pengajaran atau bahkan melakukan eksplorasi pembelajaran via tutorial secara online dan untuk mengoptimalkan hal tersebut orang tua perlu mendapatkan peningkatan pengetahuan dan keterampilan khususnya dalam literasi ICT yang tetap terfokus pada kognitif, afektif, dan juga psikomotorik serta optimalisasi seluruh aspek perkembangannya.

\section{Melakukan Kegiatan Bersama Selama di Rumah}

Terdapat berbagai ragam kegiatan yang dilakukan bersama antara orang tua dan anak selama pandemi ini berlangsung, seperti membersihkan rumah, memasak, bermain, beribadah, dll. Momen ini memberikan kesempatan bagi orang tua dan anak untuk mempererat ikatan (bonding) satu dengan lainnya, sejalan dengan hal ini UNICEF, (2020) mengungkapkan bahwa terdapat beberapa cara agar para orang tua dapat membantu proses pengasuhan dimasa pandemi ini, salah satunya adalah dengan membuat waktu yang berkualitas bersama dengan anak, contohnya untuk anak usia TK adalah dengan melibatkan anak dalam pekerjaan rumah seperti membersihkan rumah atau memasak, hal tersebut bisa dijadikan permainan yang seru. Pada titik ini, orang tua berperan sebagai pengembang berbagai kegiatan yang bisa dilakukan bersama dengan anak.

... kegiatan membuat makan dengan menu sederhana yang dilakukan bersama anggota keluarga.... (kutipan wawancara RS)

...harus bisa jadi partner kerja dalam melakukan kegiatan-kegiatan yang di anjurkan pemerintah seperti membersihkan rumah tempat tidur pakaian perabotan dan halaman yang dilakukan bersama dengan anak. (kutipan wawancara UL)

...kita bisa manfaatkan situasi rumah walupun dengan keterbatasan, dengan variasi-variasi ataupun kegiatan kegiatan yang lebih inovatif contohnya mengajak bermain bersama di dalam rumah, bercanda bersama, ataupun kegiatan membuat makan dengan menu sederhana yang dilakukan bersama anggota keluarga. Sehingga semua anggota keluarga akan merasakan tidak terlalu jenuh berada di rumah dengan sekian waktu yang lama. (kutipan wawancara RS)

Kualitas waktu yang dimiliki orang tua dan anak selama masa pandemi dapat dimanfaatkan untuk membangun kebersamaan antar anggota keluarga, Harmaini (2013) menyatakan bahwa kebersamaan orang tua sangat diperlukan karena mereka yang memahami akan tingkatan perkembangannya serta hal-hal yang mereka dibutuhkan, kebersamaan dengan anak dimulai sejak anak belum lahir hingga mereka remaja, dengan disesuaikan kebutuhan dari masing-masing anak. Kesibukan sehari-hari sering mengakibatkan waktu bersama anak menjadi terbatas. Bahkan di hari libur, ketika semua anggota keluarga berkumpul, masing-masing sibuk dengan aktivitasnya. Dengan demikian peran orang tua sebagai pengembang kegiatan dapat dilakukan bersama dengan melibatkan anak-anak dalam menentukan variasi kegiatan yang akan dilakukan sehingga anak-anak terhindar dari perasaan jenuh dan bosan. Menurut (Kementrian Pendidikan dan Kebudayaan Republik Indonesia, 2017) ada beberapa kegiatan yang dapat dilakukan bersama dengan anak untuk menciptakan waktu yang berkualitas, yaitu dengan beribadah bersama, makan bersama, bermain atau olahraga bersama, masak bersama, membersihkan rumah bersama, mendampingi anak dalam mengerjakan tugas sekolah, menonton televisi, berinternet, dan menggunakan gadget. Sejalan dengan itu Gloria (2020) menyatakan bahwa orang tua harus saling membantu satu sama lain, bersama dengan anak, kemudian mengajak anak agar berpartisipasi dalam pekerjaan rumah, seperti membereskan mainan, membereskan tempat tidur, menyiram tanaman, dan lain-lain. Dengan melakukan kegiatan bersama dengan anak selain mengusir kebosanan juga dapat mengajarkan keterampilanketerampilan baru kepada anak 


\section{Menciptakan Lingkungan yang Nyaman untuk Anak}

Bersama-sama selama tiga bulan bahkan mungkin lebih dalam kurun waktu hampir 24 jam mendorong perlunya diciptakan suasana yang nyaman untuk semua, baik secara fisik maupun psikologis. Tentu saja, orangtua seyogyanya menjadi orang yang paling tahu dan mengenal anak, bagaimana anak belajar dan kapan anak harus belajar (Prasetyono, 2008:32). Menurut Kementerian Pendidikan dan Kebudayaan (2017) bahwa peran orang tua ketika di rumah adalah membuat pembiasaan, menciptakan lingkungan yang aman, nyaman dan menyenangkan, serta mengasuh dengan positif. Memberikan rasa aman dan nyaman pada anak dapat dilakukan orang tua dengan membangun kelekatan dengan anak seperti memberikan kasih sayang melalui dekapan, gendongan, pelukan, rangkulan, dan belaian dari orang tua.

...kita tidak terlalu kaku dengan jadwal-jadwal, kegiatan-kegiatan yang memang seharusnya dilakukan oleh anggota keluarga, oleh anak-anak, baik di dalam jam pembelajaran maupun di dalam hal-hal lain. Kita bisa manfaatkan situasi rumah walupun dengan keterbatasan... (kutipan wawancara RS)

...disaat seperti ini orang tua harus bisa memberikan yang terbaik dalam menghadapi atau menemani anak.. seperti harus bisa menjadi orang tua sekaligus guru dalam membantu anak mengerjakan tugas-tugas nya dari sekolah, kemudian besok nya harus bisa jadi teman yg bisa menyeimbangi mood anak ketika anak ingin bermain dan bisa saja besok nya lagi kita harus bisa jadi partner kerja dalam melakukan kegiatan...(kutipan wawancara UL)

...menghilangkan rasa kejenuhan anak itu kita bisa memotivasinya, kita mendukungnya, biarin anak mencari apa sesuatu untuk mengikuti...(kutipan wawancara SF)

Menciptakan lingkungan yang nyaman sejalan dengan pendapat Raraswati (dalam Hatimah, 2016) yang menyatakan bahwa peran keluarga salah satunya yaitu membuat suasana belajar yang menyenangkan selama di rumah, menumbuhkan budi pekerti, dan prestasi. Menurut Kementerian Pendidikan dan Kebudayaan, (2017) hal tersebut penting dilakukan untuk pertumbuhan dan perkembangan anak dan mempererat hubungan antara orang tua dan anak, serta memberikan dorongan agar anak percaya diri dan untuk menciptakan lingkungan tidak hanya aman untuk anak, tetapi juga nyaman serta menyenangkan, dan dapat dilakukan dengan cara melakukan kegiatan bersama, seperti bermain, mengerjakan pekerjaan rumah sesuai kemampuannya, mengobrol, dan melakukan hal yang disenangi anak.

\section{Menjalin Komunikasi yang Intens dengan Anak}

Peran orang tua salah satunya adalah menjalin komunikasi yang baik dengan anak. Menurut Murtiningsih (2013) menjalin komunikasi yang dilakukan oleh orang tua dan anak menjadi hal penting karena dengan begitu akan mempererat hubungan orang tua dan anak. Melalui komunikasi, maka orangtua akan dapat mengetahui keinginan anak serta orang tua dapat menyampaikan yang diinginkan atau harapan serta dukungan kepada anak. Dengan begitu anak akan semakin terbuka kepada orang tua, begitupun sebaliknya orang tua akan semakin terbuka kepada anaknya, hal tersebut dapat membuat suasana keluarga yang hangat dan nyaman.

...sekali-kali kita coba memberikan candaan lucu, cerita-cerita tentang sejarah, ataupun cerita tentang kesulitan-kesulitan yang dihadapi anak...(kutipan wawancara $R S$ )

...mengkomunikasikan supaya anak disiplin terhadap waktu dalam belajar, tujuannya untuk mendisiplinkan anak selama belajar di rumah (kutipan wawancara SF)

Komunikasi yang positif akan membangun pengasuhan positif dalam keluarga, yang ditunjukkan dengan mendengarkan dengan penuh perhatian serta fokus terhadap pembicaraan. Komunikasi dapat dikatakan efektif apabila dalam kegiatan komunikasi 
komunikator menghindari kesalahan saat berkomunikasi khususnya pada saat proses mendidik anak (Sofyan, 2019). Ketika bermain, berlangsung juga kegiatan mendengarkan dan mengobrol, dengan begitu komunikasi positif akan terjalin antara orang tua dan anaknya. Menurut Raraswati (dalam Hatimah, 2016) menyatakan bahwa salah satu peran keluarga adalah menciptakan lingkungan yang menyenangkan untuk belajar di rumah, serta menjalin hubungan dan komunikasi hangat dan penuh kasih saying bersama anak. Dengan begitu maka anak akan merasa nyaman, aman, dan menyenangkan berada di lingkungan keluarga.

\section{Bermain Bersama Anak}

Orang tua menyampaikan bahwa selama pandemi berlangsung, kegiatan bermain menjadi aktivitas yang paling sering dilakukan, khususnya pada orang tua yang memiliki anak usia PAUD dan SD awal (Gloria, 2020; Kementerian Pendidikan dan Kebudayaan, 2017; Kementrian Pendidikan dan Kebudayaan Republik Indonesia, 2017). Hal tersebut menunjukkan hakikat dasar dunia anak, yakni bermain. Anak dapat banyak belajar tentang sesuatu melalui kegiatan bermain, dan bermain juga salah satu bagian dari pertumbuhan dan perkembangan anak yang sangat penting (Prasetyono, 2008:5). Sejalan dengan yang tercantum pada Kementerian Pendidikan dan Kebudayaan, (2017) bahwa dunia anak adalah bermain, melalui bermain, menuntun pada perkembangan anak yang cerdas, ceria dan selalu sehat. Sebagian besar anak-anak menggunakan waktunya untuk bermain, baik itu bermain sendiri maupun dengan temannya. Data dilapangan menunjukkan bahwa area bermain yang dieksplorasi selama pandemi adalah di dalam ruangan dan juga di luar ruangan. Pada keluarga yang masih memiliki akses ke luar ruangan seperti halaman rumah atau bagian belakang rumah dimanfaatkan orang tua untuk bermain bersama seperti bermain ayunan, mancing ikan, mencari cacing, ngangon entok, menanam bunga, main air, dll., sementara kegiatan bermain di dalam rumah lebih banyak dilakukan dengan menggunakan mainan yang ada seperti pesawat, kereta, mobil-mobilan, dll demikian juga kegiatan menonton tv dan bermain gawai juga menjadi aktivitas bermain yang sering dilakukan.

\section{...anak-anak pun diberi kebebasan untuk bermain..... bermain dengan gadget. (kutipan wawancara}

SF)

...anak biasanya bermain ayunan, mencari cacing, ngangon entok, mancing, nanam tanaman, ngejarngejar kucing... kalau di dalam rumah biasanya main mobi-mobilan, pesawat, kereta, nonton TV... tapi bermainnya ya interaksinya terbatas hanya dengan keluarga saja...(kutipan wawancara SP)

...mengajak anak untuk main, bercanda tawa, tapi tetap memperhatikan batasan candaan kita agar anak menghormati orang tuanya...(kutipan wawancara ED)

...contohnya mengajak bermain bersama di dalam rumah, bercanda bersama...(kutipan wawancara $R S)$

...memberikan kebebasan anak buat main, menuruti main anak sesuka hatinya, terus juga tidak mengkekang anak. Ga lupa juga untuk mendukung anak buat belajar sambil bermain, dan asal jangan keluar rumah, karena situasi saat ini lagi rawan (kutipan wawancara SS)

Kegiatan bermain bersama akan mendorong anak-anak untuk berperilaku positif sesuai dengan kebutuhan dan harapan anak, dan diharapkan hubungan yang terjalin saat bermain bersama akan secara konsisten dapat mencegah perilaku bermasalah serta sebagai salah satu cara membangun dan mempertahankan suasana keluarga yang positif (Bluth \& Wahler, 2011). Kebersamaan dan keakraban dalam keluarga akan membangun pengasuhan positif, yang mana didalamnya mengandung dimensi kasih sayang (compassion), yang didefinisikan sebagai keinginan untuk mewakili emosi seseorang dalam meringankan penderitaan (Lazarus dan Lazarus, 1994, dalam Duncan et al., 2009). Pola pengasuhan positif pada dasarnya dilakukan untuk memenuhi kebutuhan dasar anak seperti kasih sayang, rasa aman dan rasa nyaman. 
DOI: 10.31004/obsesi.v5i1.541

\section{Menjadi Role Model bagi Anak}

Orang tua merupakan pemimpin di dalam keluarga, di mana orang tua adalah seseorang yang paling dewasa di antara anggota keluarga lainnya. Dalam struktur keluarga, anak-anak akan mengikuti dan mencontoh perilaku orang tua. Rakhmawati (2015) menyatakan bahwa anak akan meniru perilaku orang tuanya karena anak melihat hal tersebut baik itu yang positif ataupun yang negatif, hal yang ditiru oleh anak contohnya meniru kebiasaan, pergaulan orang tua, perilaku, ataupun aktivitas sehari-hari yang dilakukan orang tua. Dengan begitu orang tua menjadi sumber pertama anak untuk belajar karena pada dasarnya anak memiliki dorongan untuk meniru suatu pekerjaan, baik itu dari orang tua maupun dari orang lain (Taubah, 2016).

...memberikan suatu contoh terhadap anggota keluarganya, bahwa pada masa pandemi corona yang pertama harus dijaga adalah kesehatan, yang kedua kegiatan-kegiatan rutin yang sifatnya pendidikan ataupun kerja itu bisa dilakukan dari rumah...(kutipan wawancara $R S$ )

...membiasakan mencuci tangan dan juga kaki sehabis beraktivitas main di luar, dengan mencuci bersama, supaya jadi contoh buat anak...(kutipan wawancara SP)

...karena interaksinya sekarang terbatas, jadi AH sama IZ jarang bertengkar saat main bersama, kita juga membiasakan mengucapkan terima kasih...atau maaf atau punten...kalo dikasih sesuatu atau melakukan sesuatu...(kutipan wawancara SP)

Dalam pengasuhan orang tua berperan untuk membimbing dan mendidik anakanaknya agar dapat menjalankan kehidupan bermasyarakat. Sejalan dengan hal tersebut, Jannah (2012) mengemukakan bahwa melalui pengasuhan dapat membentuk perkembangan moral pada anak. Untuk membentuk perkembangan moral yang baik, maka diperlukannya peran model yang baik pula yang dicontohkan sehari-hari di rumah. Peran orangtua sebagai role model akan mendorong anak-anak berperilaku positif sesuai harapan, dan mencegah perilaku bermasalah dikemudian hari.

\section{Memberikan Pengawasan pada Anggota Keluarga}

Fungsi pengawasan dilakukan orang tua terhadap pola perilaku hidup bersih dan sehat (PHBS) dan pelaksanaan kegiatan belajar anak. Peran pengawasan menunjukkan bahwa dalam keluarga, orang tua merupakan subsistem terkait interaksi orang tua dengan anak, yang di dalamnya berperan untuk melindungi, membesarkan dan mendisiplinkan anak (Pratiwi et al., 2018). Sejalan dengan hal itu, disebutkan dalam Peraturan Pemerintah Nomor 87 Tahun 2013 (dalam Puspitawati, 2018: 135), bahwa fungsi keluarga adalah untuk melindungi dengan menumbuhkan dan memberikan rasa aman dalam keluarga baik secara fisik, ekonomi, dan psikososial, serta kehangatan. Bentuk dari melindungi anggota keluarga di sini, orang tua sekaligus berperan sebagai pengawas anak-anaknya dari hal-hal yang membuat anak tidak aman ataupun yang lainnya.

...peran orang tua sebagai mengawas di keluarga atau pengawas anggota keluarganya dari penyebaran covid-19 dengan cara memberikan edukasi kepada anggota keluarga terutama kepada anak-anak,...(kutipan wawancara $R S$ )

...selain menjadi pengawas dalam sisi penyebaran corona atau sisi kesehatannya, juga dalam hal ini tetap mengarahkan dan ngasih motivasi atau dorongan untuk tetap melaksanakan dan mengikuti aktivitas belajar nya...(kutipan wawancara $R S$ )

Peran pengawasan merupakan salah satu cara untuk melindungi anggota keluarga. Peran ini berkaitan dengan dimensi pemahaman dan penerimaan untuk tidak menghakimi, serta melibatkan perhatian penuh dari berbagai atribusi dan harapan yang dibuat orang tua berkaitan dengan persepsi interaksi pengasuhan (Duncan et al., 2009). Persepsi interaksi pengasuhan yang positif terjadi ketika adanya pemahaman dan penerimaan antara anak dengan orang tua sehingga memberikan rasa aman untuk anak. 


\section{Menafkahi dan Memenuhi Kebutuhan Keluarga}

Peran orang tua sebagai pencari nafkah bukan hanya di masa pandemi Covid-19 saja, melainkan di situasi normal pun, orang tua memiliki peranan tersebut. Namun, kondisi pandemi ini memaksa keluarga untuk bekerjasama lebih keras baik ayah juga ibu dalam memenuhi kebutuhan dasar keluarga. Tak sedikit keluarga yang kehilangan pekerjaaan, yang berakibat pada hilangnya penghasilan dan tidak terpenuhinya kebutuhan ekonomi keluarga. Padahal salah satu fungsi keluarga adalah fungsi ekonomi, yakni keluarga menjadi pendukung pemenuhan kebutuhan dalam mencapai kesejahteraan keluarga (PP No 87 Tahun 2014, dalam Puspitawati, 2018: 136).

...berusaha dan berikhtiar. Usahanya ya mencari uang buat mencukupi kebutuhan keluarga, jangan cuma diem di rumah, kecuali yang punya gaji tetap, yang wiraswasta mah susah... (kutipan wawancara ED)

...membantu suami dalam bidang ekonomi. Gara-gara virus ini rata-rata keluarga itu terdampak ekonomi, sehingga perlu ada usaha tambahan...(kutipan wawancara LQ)

Pemenuhan kebutuhan dasar keluarga merupakan upaya untuk memenuhi perawatan, pengasuhan dan pendidikan. Dalam hal ini, terdapat kewajiban dan tanggung jawab keluarga yakni untuk memenuhi kebutuhan dasar anak, seperti mengasuh, memelihara, mendidik, dan melindungi anak (Undang-Undang Republik Indonesia Nomor 35 Tahun 2014 Tentang Perubahan Atas Undang-Undang Nomor 23 Tahun 2002 Tentang Perlindungan Anak, 2014). Kebutuhan dasar keluarga yang mampu terpenuhi merupakan bentuk dari keluarga yang sejahtera atau harmonis (Puspitawati, 2013). Ketidakberfungsian keluarga dalam memenuhi kebutuhan dasar akan berdampak pada keharmonisan keluarga, apalagi di situasi saat ini. Upaya keluarga dalam mencukupi kebutuhan merupakan bagian dari pengasuhan positif, yang mana hubungan dibangun terus-menerus antara orang tua dan anak atau antar anak-anak yang termasuk di dalamnya mengasuh, mengajar, memimpin, berkomunikasi, dan menyediakan kebutuhan anak secara konsisten dan tanpa syarat (Seay et al., 2014).

\section{Membimbing dan Memberi Motivasi Kepada Anak}

Kegiatan belajar dari rumah (BDR) yang dilakukan anak-anak selama pandemi berlangsung memunculkan beragam kondisi diantaranya adalah jenuh dan menurunnya semangat anak-anak dalam belajar. Seperti yang disebutkan dalam penelitian Nurkholis (2020) bahwa dampak dari situasi pandemi Covid-19 pada peserta didik adalah kejenuhan dan kebosanan. Dalam hal ini peran orang tua adalah membimbing dan memberikan motivasi kepada anak, agar anak tetap bersemangat dalam melakukan kegiatan di rumah. Pada dasarnya anak memiliki motivasi untuk melakukan suatu hal, apabila ia mendapatkan sebuah dorongan dari orang-orang terdekat seperti orang tua (Yulianti, 2014). Menurut Sardiman (Harahap, 2018) mengemukakan bahwa motivasi adalah serangkaian usaha dalam menciptakan kondisi tertentu untuk memberi rangsangan agar seseorang ingin melakukan sesuatu. Peran-peran ini dimunculkan oleh orang tua, sebagai salah satu cara pengasuhan orang tua terhadap anaknya. Sebagaimana dipaparkan oleh beberapa orang tua di bawah ini.

...anak-anak perlu bimbingan lebih dari orang tua. Sehingga kita sebagai ibu harus jadi lebih sabar kepada anak karena anak kalau belajar sama orang tua nya beda kalau sama gurunya lebih nurut. Ketika pembibingan dan pengarahan pun tidak membentak anak, agar anak termotivasi buat belajar... (kutipan wawancara LQ)

...mengarahkan dan ngasih motivasi atau dorongan untuk tetap melaksanakan dan mengikuti pembelajaran di rumah sesuai dengan yang di haruskan oleh lembaga pendidikan... (kutipan wawancara $R S$ ) 
DOI: 10.31004/obsesi.v5i1.541

...ketika anak mulai bosan ajak anak untuk ikut masak atau juga membantu anak belajar dirumah....menyeimbangi mood anak ketika anak ingin bermain... (kutipan wawancara UL)

...supaya tidak jenuh di rumah terus, saya biasanya ajak anak ke luar untuk main di halaman rumah...(kutipan wawancara SP)

Orang tua perlu membaca situasi yang dialami oleh anak dan menunjukkan sikap responsiveness terhadap situasi tersebut. Responsiveness, meliputi kasih sayang, dukungan, dan kehangatan (Lestari, 2012). Dalam membimbing dan memberikan motivasi kepada anak, orang tua perlu fokus pada cara berkomunikasi antara orang tua dengan anak, komunikasi dapat dikatakan efektif apabila dalam berkomunikasi orang tua dengan anak mempunyai hubungan yang dekat, menyukai, memahami, dan terbuka satu sama lain (Jatmikowati, 2018). Selain itu, membimbing dan memberikan motivasi memerlukan kesadaran emosi yang merupakan dasar dari pengasuhan anak, karena emosi yang kuat memiliki pengaruh yang kuat dalam memicu proses berpikir secara otomatis termasuk di antaranya perilaku yang cenderung merusak (Duncan et al., 2009).

\section{Memberikan Edukasi}

Memberikan edukasi atau pendidikan merupakan fungsi dan peran keluarga. Berdasarkan PP No 87 Tahun 2014 (Puspitawati, 2018: 136) terdapat fungsi keluarga, salah satunya fungsi sosialisasi dan pendidikan, yakni keluarga berperan memberikan pengasuhan, merawat dan mendidik keturunan berdasarkan tahap perkembangannya, yang bertujuan untuk mencetak keturunan yang berkualitas di lingkungan dan kehidupan mendatang. Keluarga pada dasarnya adalah forum pertama untuk memberikan pendidikan kepada anggota keluarganya (Hyoscyamina, 2011). Pendidikan pertama dan utama anak diawali sejak anak berada di lingkungan keluarga, khususnya didominasi oleh peranan sang ibu (Lathifah \& Helmanto, 2019). Selain itu, terdapat beberapa berperan dalam orang tua untuk pendidikan anak-anaknya yakni dalam membimbing sikap serta keterampilan yang mendasar, seperti pendidikan agama untuk patuh terhadap aturan, dan untuk pembiasaan yang baik (Nurlaeni \& Juniarti, 2017).

... orang tua itu sebagai guru di rumah, karena sekarang kan sekolahnya libur jadi dilakukan di rumah... (kutipan wawancara LQ)

...terutama dengan memberikan pengertian, edukasi yang sejelas-jelasnya... (kutipan wawancara RS) ...ibu sebagai pendidik di rumah kepada anak-anaknya, langsung memberikan bimbingan dan arahan, menggantikan peran guru di sekolah untuk mengadakan pengajaran... (kutipan wawancara SF)

Sebelum terjadinya pandemi tugas pendidikan akademik seringkali di limpahkan kepada guru, yang rata-rata berorientasi pada penyampaian materi-materi pelajaran tertentu. Namun situasi pandemi ini, mendorong orang tua untuk lebih berperan. Nilai edukasi atau pendidikan yang diberikan orang tua hendaknya berorientasi pada penanaman perilaku-perilaku positif yang dapat menunjang tercapainya kesejahteraan anak. Terkait peran orang tua dalam mendampingi anak belajar di rumah pada dasarnya mengembalikan fitrah awal orang tua, yakni pendidik pertama dan utama dikeluarganya. Pramudyani (2014) menyatakan bahwa orang tua memiliki peran untuk mendidik anak dan menjadi guru di rumah bagi anak-anaknya khususnya ibu. Berdasarkan survey yang dilakukan oleh Arsendy et al. (2020) menyatakan bahwa terdapat kelompok ibu yang menyediakan waktu lebih banyak sekitar 2-3 jam per hari dibandingkan sosok ayah yang menyediakan waktu sekitar kurang dari 1 jam untuk mendampingi anak ketika belajar di rumah. Dalam hal ini dapat dikatakan bahwa orang tua memiliki peran aktif dalam mendampingi anak belajar di rumah meskipun peran ibu lebih banyak dalam meluangkan waktu. Sejalan dengan hal tersebut Gloria (2020) menyatakan bahwa dengan adanya pandemi COVID-19 ini memiliki hikmah tersendiri untuk orang tua, karena orang tua bisa memonitoring anak nya secara langsung juga dapat melakukan bimbingan secara langsung dalam proses pembelajaran anak- 
anaknya, sehingga anak akan lebih dekat dengan orang tuanya serta orang tua akan mengetahui kesulitan yang di hadapi anak nya dan peran orang tua adalah untuk membantu anak dalam menghadapi kesulitan-kesulitan tersebut.

\section{Memelihara Nilai Keagamaan}

Keluarga menjadi tempat utama untuk menanamkan nilai-nilai keagamaan. Keluarga merupakan forum pendidikan pertama dan utama untuk pembentukan karakter anak (Hyoscyamina, 2011). Sebagaimana yang tercantum pada Peraturan Pemerintah No 87 Tahun 2014 (dalam Puspitawati, 2018: 135) fungsi keagamaan, yakni keluarga mengembangkan kehidupannya tidah hanya dengan menghayati saja, tetapi juga dengan memahami serta melaksanakan nilai-nilai dan norma agama dengan penuh iman dan taqwa kepada Tuhan YME. Fungsi ini dilakukan oleh peran orang tua sebagai pembina di dalam keluarganya. Sebagaimana dipaparkan oleh salah satu orang tua di bawah ini.

...tentunya ngasih pendidikan agama ke anak-anak, seperti mengajarkan ngaji, membantu merawat anak...(kutipan wawancara ED)

...sholat 5 waktu jangan ketinggalan, kalau anak saya lupa diingatkan, dan kalau anak saya ga mau atau nanti, nanti, kita harus terus menggiringnya agar dia mau melaksanakan sholat 5 waktu. Kemudian untuk mengaji, anak saya khususnya kalau mengaji pengen sama bapaknya. Ya terpaksa bapaknya harus membimbingnya memberikan pelajaran membaca al-quran dengan menggunakan iqro (kutipan wawancara SF)

Memelihara nilai-nilai agama merupakan salah satu dari dimensi pola pengaturan diri yang bijaksana dalam pengasuhan, apalagi di Indonesia yang sangat menjunjung tinggi nilai-nilai keagamaan. Dalam hal ini orang tua perlu memiliki keterampilan dalam memberikan arahan, membiasakan ibadah, dan menyampaikannya sesuai dengan perkembangan anak. Dalam mencapai pengaturan diri yang baik khususnya dalam melaksanakan niali-nilai keagamaan anak-anak perlu memiliki kematangan sosial emosi yang baik, untuk bisa mencapai itu maka orang tua perlu memiliki sikap toleran, suportif, dan terampil mengatur emosi negatif saat anak sedang berperilaku dengan emosi negatifnya (Sofyan, 2019) termasuk diantaranya saat melaksanakan peribadatan.

\section{Melakukan Variasi dan Inovasi Kegiatan di Rumah}

Peran sebagai pengembang kegiatan dilakukan orang tua dengan menyediakan beragam kegiatan dan melakukan berbagai inovasi saat BDR. Orang tua secara proaktif memanfaatkan peluang-peluang yang ada sebagai bagian dari pembelajaran termasuk diantaranya pemanfaatan teknologi informasi. Pemanfaatan teknologi informasi ini diharapkan dapat membantu anak-anak untuk mengembangkan potensi, minat, dan bakat yang dimiliki, sehingga dapat menghasilkan life skill secara sederhana dari teknologi tersebut (Hardiyana, 2016). Aplikasi yang dimiliki di HP ataupun fitur-fitur lain yang dimiliki gawai dimanfaatkan sebaik-baiknya untuk pembelajaran. Dalam hal ini variasi-variasi dan inovasi selama berkegiatan di rumah dilakukan dengan menyenangkan.

... tapi kadang-kadang kita juga ambil sisi positifnya, anak saya suka nonton tiktok, suka nonton youtube, anak saya kebetulan suka nonton youtube-youtube yang gimana caranya biar bisa dapet pelajaran sulap. Saya seneng gitu liat anak saya nonton gimana tutorial biar bisa jadi pesulap (kutipan wawancara SF)

...dengan variasi-variasi ataupun kegiatan kegiatan yang lebih inovatif...(kutipan wawancara RS)

...saya buat ayunan dari ban dan selang air untuk anak supaya senang...(kutipan wawancara SP)

Variasi kegiatan yang dilaksanakan orang tua memang diperlukan untuk memelihara interaksi yang baik dalam pengasuhan anak. Variasi ini selain diperuntukan 
bagi anak, juga bagi orang tua itu sendiri. Untuk menjaga agar anak tetap belajar menyenangkan, maka orang tua juga perlu memiliki pengalaman atau kegiatan yang menyenangkan juga. Dalam pengasuhan positif, salah satu dimensi yang dapat menunjang keberhasilan peran orang tua di sini adalah peran kasih sayang dalam memenuhi kebutuhan dan kenyamanan pada anak yang tepat. Kasih sayang juga dimaknai sebagai emosi untuk memfasilitasi kerja sama dan menjadi benteng bagi orang yang lemah atau menderita (Goetz et al., 2010, dalam Sofyan, 2019).

\section{SIMPULAN}

Hasil penelitian menunjukkan bahwa secara umum peran orang tua yang muncul selama pandemi covid-19 adalah sebagai pembimbing, pendidik, penjaga, pengembang dan pengawas dan secara spesifik menunjukkan bahwa peran orang tua adalah menjaga dan memastikan anak untuk menerapkan hidup bersih dan sehat, mendampingi anak dalam mengerjakan tugas sekolah, melakukan kegiatan bersama selama di rumah, menciptakan lingkungan yang nyaman untuk anak, menjalin komunikasi yang intens dengan anak, bermain bersama anak, menjadi role model bagi anak, memberikan pengawasan pada anggota keluarga, menafkahi dan memenuhi kebutuhan keluarga, dan membimbing dan memotivasi anak, memberikan edukasi, memelihara nilai keagamaan, melakukan variasi dan inovasi kegiatan di rumah.

\section{UCAPAN TERIMA KASIH}

Ucapan terima kasih disampaikan kepada seluruh responden dalam penelitian ini juga kepada Prodi PGPAUD Fakultas Ilmu Pendidikan Universitas Pendidikan Indonesia atas kesempatan mengekplorasi dunia pendidikan anak usia dini di perguruan tinggi.

\section{DAFTAR PUSTAKA}

Alfiana, E. (2013). Pola Asuh Orang Tua Terhadap Anak Dalam Keluarga Pada Bidang Pendidikan Di Dusun Pandanan Desa Pandanan Kecamatan Wonosari Kabupaten Klaten [Universitas Negeri Yogyakarta]. In Skripsi. https://doi.org/10.1016/j.bbapap.2013.06.007

Alwasilah, A. C. (2002). Pokoknya kualitatif: dasar-dasar merancang dan melakukan penelitian kualitatif. Pustaka Jaya.

Ansori. (2020). Peran Kepala Sekolah di Saat Pandemi Covid-19. Www.Pintar.Tanotofoundation.Org. https://www.pintar.tanotofoundation.org/peran-kepala-sekolah-di-saat-pandemicovid-19/

Arsendy, S., Sukoco, G. A., \& Purba, R. E. (2020). Riset dampak COVID-19: potret gap akses online 'Belajar dari Rumah' dari 4 provinsi. Theconversation.Com. https://theconversation.com/riset-dampak-covid-19-potret-gap-akses-online-belajardari-rumah-dari-4-provinsi-136534

Bluth, K., \& Wahler, R. G. (2011). Does Effort Matter in Mindful Parenting? Mindfulness, 2(3), 175-178. https://doi.org/10.1007/s12671-011-0056-3

Candra, A. N., Sofia2, A., \& Anggraini, G. F. (2013). Gaya Pengasuhan Orang Tua pada Anak usia Dini Ariya. Journal of Chemical Information and Modeling, 53(9), 1689-1699. https:/ / doi.org/10.1017/CBO9781107415324.004

Covid19.go.id. (2020). Data Sebaran. Covid19.Go.Id. https:/ /covid19.go.id/

Dhiva, A. A. (2016). 6 Panduan Penting Dalam Menjaga Kesehatan Anak. Parentingclub.Co.Id. https://www.parentingclub.co.id/smart-stories/6-panduan-penting-dalammenjaga-kesehatan-anak

Duncan, L. G., Coatsworth, J. D., \& Greenberg, M. T. (2009). A Model of Mindful Parenting: Implications for Parent-Child Relationships and Prevention Research. Clinical Child 
and Family Psychology Review, 12(3), 255-270. https://doi.org/10.1007/s10567-009$0046-3$

Gloria. (2020). Sehat Mental Selama di Rumah dengan Aktivitas Positif Bersama Keluarga. Ugm.Ac.Id. https://ugm.ac.id/id/newsPdf/19175-sehat-mental-selama-di-rumahdengan-aktivitas-positif-bersama-keluarga

Graha, C. (2007). Kebersihan Anak di Tangan Orang Tua Paunduan Bagi Orang Tua Untuk Memahami Perannya dalam Membantu Keberhasilan. PT Elex Media.

Harahap, F. I. N. (2018). Pengaruh Hasil Program Parenting Dan Pola Asuh Orang Tua Terhadap Peningkatan Motivasi Belajar Anak Usia Dini. Al-Muaddib : Jurnal Ilmu-Ilmu Sosial \& Keislaman, 3(1), 1-15. https://doi.org/10.31604/muaddib.v1i1.367

Hardiyana, A. (2016). Optimalisasi Pemanfaatan Teknologi Informasi Dan Komunikasi Dalam Pembelajaran Paud. Awlady: Jurnal Pendidikan Anak, 2(1), 1-12. https:// doi.org/10.24235/awlady.v2i1.762.g603

Harmaini. (2013). Keberadaan Orang Tua Bersama Anak. Jurnal Psikologi UIN Sultan Syarif Kasim Riau.

Hatimah, I. (2016). Keterlibatan Keluarga Dalam Kegiatan Di Sekolah Dalam Perspektif Kemitraan. Pedagogia, 14(2), 290-297. https://doi.org/10.17509/pedagogia.v14i2.3878

Heriyanto, H. (2018). Thematic Analysis sebagai Metode Menganalisa Data untuk Penelitian Kualitatif. Anuva. https:// doi.org/10.14710/anuva.2.3.317-324

Hyoscyamina, D. E. (2011). Peran Keluarga Dalam Membangun Karakter Anak. Jurnal Psikologi, 10(2), 144-152. https://doi.org/https://doi.org/10.14710/jpu.10.2.144-152

Ihsani, I., \& Santoso, M. B. (2020). Edukasi Sanitasi Lingkungan Dengan Menerapkan Perilaku Hidup Bersih Dan Sehat (Phbs) Pada Kelompok Usia Prasekolah Di Taman Asuh Anak Muslim Ar-Ridho Tasikmalaya. Prosiding Penelitian Dan Pengabdian Kepada Masyarakat, 6(3), 289. https:/ / doi.org/10.24198/jppm.v6i3.22987

Jannah, H. (2012). Perilaku Moral Pada Anak Usia Di Kecamatan Ampek. Bentuk Pola Asuh Orang Tua Dalam Menanamkan Perilaku Moral Pada Anak Usia Di Kecamatan Ampek Angkek, 1, 257-258.

Jatmikowati, T. E. (2018). Efektifitas Komunikasi Orang Tua Terhadap Kepribadian Intrapersonal Anak. Pedagogi: Jurnal Anak Usia Dini Dan Pendidikan Anak Usia Dini, 4(2), 1-15. https://doi.org/http:/ /dx.doi.org/10.30651/pedagogi.v4i2.1936

Kementerian Pendidikan dan Kebudayaan. (2017). Menjadi Orang Tua Hebat Untuk Keluarga dengan Anak Usia Dini. In My Hero (Vol. 98, Issue 25). Kementerian Pendidikan dan Kebudayaan. http://118.98.227.114/glnsite/wpcontent/uploads/2017/09/Juknis_PAUD.pdf

Kementrian Pendidikan dan Kebudayaan Republik Indonesia. (2017). Waktu Berkualitas Bersama Anak. Sahabatkeluarga.Kemdikbud.Go.Id. https:// sahabatkeluarga.kemdikbud.go.id/laman/uploads/Dokumen/4483_201702-13/Waktu Berkualitas Bersama Anak.pdf

Lathifah, Z. K., \& Helmanto, F. (2019). Orang Tua Sebagai Panutan Islami Untuk Anak. DIDAKTIKA TAUHIDI: Jurnal Pendidikan Guru Sekolah Dasar, 6(2), 131. https:// doi.org/10.30997/dt.v6i2.2129

Lestari, S. (2012). Psikologi keluarga : penanaman nilai dan penanganan konflik dalam keluarga (2nd ed.). Kencana.

Lutfatutatifah, Adriany, V., \& FaizahRomadona, N. (2015). Pola Asuh Orang Tua Anak Usia Dini Di Kampung Adat Benda Kerep Kota Cirebon. Jurnal Pendidikan Serantau, 1(1), 1226.

Mattewakkang, A. J. (2020). Arah Pendidikan Di Masa Pandemi Covid-19 (Refleksi Hari Pendidikan Nasional). Takalarterkini.Com. http://takalarterkini.com/arahpendidikan-di-masa-pandemi-covid-19-refleksi-hari-pendidikan-nasional/

Murtiningsih, D. (2013). Peran Orangtua Dalam Kegiatan Bermain Anak Usia Dini (4-6 Tahun) Di Rumah. Jurnal Pendidikan Luar Sekolah, 9(2), 1-21. 
http://ejournal.upi.edu/index.php/pls/article/view/5421

Nahdi, K., Ramdhani, S., Yuliatin, R. R., \& Hadi, Y. A. (2020). Implementasi Pembelajaran pada Masa Lockdown bagi Lembaga PAUD di Kabupaten Lombok Timur Abstrak. 5(1), 177-186. https://doi.org/10.31004/obsesi.v5i1.529

Nuraini, R. (2020). Kasus Covid-19 Pertama, Masyarakat Jangan Panik. Indonesia.Go.Id. https://indonesia.go.id/narasi/indonesia-dalam-angka/ekonomi/kasus-covid-19pertama-masyarakat-jangan-panik

Nurkholis. (2020). Dampak Pandemi Novel-Corona Virus Disiase ( Covid-19 ) Terhadap. 6(1), 39_ 49.

Nurlaeni, N., \& Juniarti, Y. (2017). Peran Orang Tua Dalam Mengembangkan Kemampuan Bahasa Pada Anak Usia 4-6 Tahun. Jurnal Pelita PAUD. https:// doi.org/10.33222/pelitapaud.v2i1.196

Oktaviani, S., Yanzi, H., \& Pitoewas, B. (2017). Peranan Orang Tua Terhadap Upaya Perlindungan Kesehatan Reproduksi Di Desa Margoyoso Kecamatan Sumberejo Kabupaten Tanggamus Lampung. In Skripsi. Universitas Lampung.

Peraturan Pemerintah Republik Indonesia Nomor 21 Tahun 1994 Tentang Penyelenggaraan Pembangunan Keluarga Sejahtera, Pub. L. No. 21 (1994).

Prabhawani, S. W. (2016). Pelibatan Orang Tua Dalam Program Sekolah Di Tk Khalifah Wirobrajan Yogyakarta. Pendidikan Guru PAUD S-1.

Pramudyani, A. V. R. (2014). Peran orang tua sebagai guru pertama bagi anak usia dini. $\begin{array}{llll}\text { Jurnal Anak Uia Dini 160-173. } & \text { Edu, }\end{array}$ https://doi.org/https://doi.org/10.21831/jppm.v1i2.2686

Prasetyono, D. S. (2008). Rahasia Mengajarkan Gemar Membaca Pada Anak Sejak Dini. Think Jogjakarta.

Pratiwi, M. R., Mukaromah, \& Herdiningsih, W. (2018). Peran Pengawasan Orangtua Pada $\begin{array}{llll}\text { Anak Pengguna Media } & \text { Sosial. }\end{array}$ https://doi.org/https://doi.org/10.46426/jp2kp.v22i1.73

Undang Undang Republik Indonesia Nomor 20 Tahun 2003, (2003).

Puspitawati, H. (2013). Konsep dan Teori Keluarga. Gender Dan Keluarga, 4(Zeitlin 1995), 116. https:// doi.org/10.1249/01.mss.0000074580.79648.9d

Puspitawati, H. (2018). Ekologi Keluarga: Konsep dan Lingkungan (1st ed.). IPB Press.

Rakhmawati, I. (2015). Peran Keluarga dalam Pengasuhan Anak. Jurnal Bimbingan Konseling Islam, 6(1). https://doi.org/10.21043/kr.v6i1.1037

Rompas, Y. (2018). Hubungan Peran Orang Tua Dengan Perilaku Hidup Bersih Dan Sehat Anak Usia Sekolah Di Sd Inpres Talikuran Kecamatan Kawangkoan Utara. JURNAL KEPERAWATAN.

Rosdiana, A. (2006). Partisipasi Orangtua Terhadap Pendidikan Anak Usia Dini: Survei Pada Kelompok Bermain Di Kota Yogyakarta. Jurnal Ilmiah VISI, 1(2), 62-72. https://doi.org/https://doi.org/10.21009/JIV.0102.10

Sanders, M. R. (2008). Triple P-Positive Parenting Program as a Public Health Approach to Strengthening Parenting. Journal of Family Psychology. https:// doi.org/10.1037/08933200.22.3.506

Seay, A., Freysteinson, W. M., \& McFarlane, J. (2014). Positive Parenting. Nursing Forum. https:// doi.org/10.1111/nuf.12093

Sofyan, I. (2019). Mindful Parenting: Strategi Membangun Pengasuhan Positif dalam Keluarga. Journal of Early Childhood Care and Education, 1(2), 41. https://doi.org/10.26555/jecce.v1i2.241

Taubah, M. (2016). Pendidikan Anak Dalam Keluarga Perspektif Islam Mufatihatut Taubah (Dosen STAIN Kudus Prodi PAI). JUmal Pendidikan Agama Islam, 3(1), 109-136. https://doi.org/https://doi.org/10.15642/jpai.2015.3.1.109-136

Undang-Undang Republik Indonesia Nomor 35 Tahun 2014 tentang Perubahan Atas Undang-Undang Nomor 23 Tahun 2002 Tentang Perlindungan Anak, Pub. L. No. 35 
(2014).

UNICEF. (2020). Kiat Pengasuhan di Tengah Wabah Virus Corona (COVID-19). Unicef.Org. https://www.unicef.org/indonesia/id/coronavirus/kiat-pengasuhan-COVID$19 \#$ top

WHO. (2020). Coronavirus disease (COVID-19) advice for the public: Advocacy. Www.Who.Int. https://www.who.int/emergencies/diseases/novel-coronavirus-2019/advice-forpublic/healthy-parenting

worldometers.info. (2020). COVID-19 Coronavirus Pandemic. Www.Worldometers.Info. https:// www.worldometers.info/coronavirus/\#page-top

Yin, R. . (2003). Case Study Research: Design and Methods. 3rd Edition, Sage, Thousand Oaks. Open Journal of Social Sciences.

Yulianti, T. R. (2014). Peranan Orang Tua Dalam Mengembangkan Kreativitas Anak Usia Dini (Studi Kasus Pada Pos PAUD Melati 13 Kelurahan Padasuka Kecamatan Cimahi Tengah). Jurnal EMPOWERMENT, 4(1), 11-24. https:// doi.org/https:// doi.org/10.22460/empowerment.v3i1p11-24.569

Zahrok, S., \& Suarmini, N. W. (2018). Peran Perempuan Dalam Keluarga. IPTEK Journal of Proceedings Series. https:// doi.org/10.12962/j23546026.y2018i5.4422 